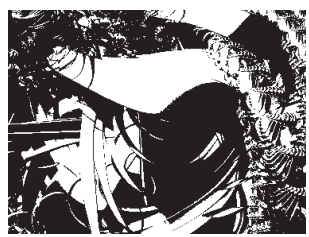

doi:10.5559/di.20.1.13

\title{
HOMEROVE ODGOJNE VRIJEDNOSTI
}

Marko PRANJIĆ

Hrvatski studiii, Zagreb

UDK: 821.14.09 Homerus:37

Pregledni rad

Primljeno: 1. 6. 2009.

Autor priloga poseže za najreprezentativnijim djelima europske kulture iz vremena rane antike, Homerovom Ilijadom i Odisejom. Cili mu je pokazati da se njihovi pojedini dijelovi mogu iščitavati i interpretirati ne samo književno, iako su to prije svega epska književna djela, nego i pedagoški. Metodom detektiranja upozorava na pojedina pjevanja i u sklopu njih određene stihove, a potom hermeneutski, odnosno analitički, upozorava na njihovu odgojnu i pedagošku težinu ili značenje te ih istodobno interpretira u skladu sa suvremenim dostignućima odgojnih znanosti. Kao glavnom okosnicom svog istraživanja poslužio se kriterijem motrenja ljudskog odrastanja u Homerovo vrijeme kroz životne dobi: djetinjstvo, preadolescencija, adolescencija, ali i govora o uzoru i slavi. U vremenu kad se zbog određene prakse življenja dovode u pitanje pojedine društvene, a samim tim i odgojne, vrijednosti ne toliko na razini odbacivanja načela koliko na praksi koja ga uvijek ne slijedi, upućuje se na izvore kako bi se vidio nastanak $i$ življenje vrijednosti u počecima europskoga civilizacijskog kruga, kojemu pripada i Hrvatska.

Ključne riječi: Homer, novorođenče, dječak, mladić, odgoj, odgajanik, odgajatelj

$\triangle \quad$ Marko Pranjić, Hrvatski studiji Sveučilišta u Zagrebu, Kampus Borongai, Borongajska cesta 83d, 10000 Zagreb, Hrvatska. E-mail: mpranjic@hrstud.hr

Odgoj je u staroj Grčkoj vrijedio samo za plemstvo (Jaeger, 1989.; Marrou, 1977.), a ticao se i tjelesne i duševne razine čovjeka, s nakanom da se dođe do jake osobnosti. U tom okruženju odgojena osoba morala je biti odlučna, poduzetna i u borbi okretna, o čemu se naveliko govori u Homerovim epovima (Freemans, 1932.), tako da se u njegovu životnom i obrazovnom 
DRUŠ. ISTRAŽ. ZAGREB GOD. 20 (2011), BR. 1 (111)

STR. $249-267$

PRANJIĆ, $M$. HOMEROVE ODGOJNE.. idealu naslućuju crte, ali još uvijek ne i pojam budućega sa-

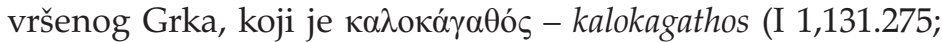
4,179; 21,108; O 17,307), ${ }^{1}$ a iznjedrit će ga kasnije atenski pristup odgoju (Jaeger, 1989., 46), što će Rimljani slobodno prevesti kao "mens sana in corpore sano". Homerov helenski svijet nalazi se $u$ povojima svoga kulturnog razvoja, ${ }^{2}$ pa nije moguće govoriti strogo o njegovu odgojnom sustavu i pratećim ustanovama. Ovdje je riječ tek o odgojnim običajima i navikama, a manje o njegovim promišljenim načelima i pravilima. Ukratko, odgoj Grka u Homerovo vrijeme isključivo je vezan uz obitelj, koncentriran je na praktično, a odgajalo se motrenjem odraslih dok su bili u akciji. ${ }^{3}$

\section{ODGOJNI ODNOS PREMA NOVOROĐENČETU}

Prvo staranje oko novorođenčeta pripalo je majci, iako ona u mnogo slučajeva nije uvijek sama hranila svoje dijete. Naprotiv, povjeravalo ga se dvorkinji, robinji, odnosno dojilji ili njegovateljici, kojoj je to bila dužnost i svojevrsna profesija. To se vidi u kući najslavnijega trojanskog heroja Hektora, ${ }^{4} \mathrm{u}$ trenutku, naime, kad se on dolazi oprostiti od svoje supruge Andromahe, sluteći da mu je to i posljednji susret sa ženom i sinom Astijanaksom (I 6,399-403) jer su Ahejci s golemim vojnim snagama već na vratima Troje. U Andromahinoj pratnji je "dojilja" koja je pošla za Andromahom "u rukama noseći dijete" (I 6,389.399-400; O 1,435). Tako othranjena djeca, a zbog majčinskog odnosa prema njima, bila su vrlo naklonjena i odana svojim dojiljama i u djetinjstvu (I 6,467) i u poodmakloj dobi (O 22,394-429). O tome nam svjedoči i Odisejev odnos prema vlastitoj dojilji Eurikleji, koja je bila sluškinja njegova oca Laerta (O 22,394.419; 23,25.39.69), pa su se prema njoj krajnje korektno odnosili i kasnije (O 1,430-433; 22,391s; 411ss).

Po svemu sudeći, antičkom Grku nije se činilo dobrim da dječak odrasta samo pod materinom i dojiljinom paskom, jer se izlagao riziku razmaženosti (O 1,297-298; 2,270-280), iako se njegovala nježnost i samog oca. To Homer posebno ističe u susretu Hektora i Andromahe, kad žena savjetuje svojemu mužu da se ne izlaže riziku i da ne ide u rat iz kojeg ona sluti da joj muž neće izvući živu glavu. Upravo je to trenutak kad beskompromisni trojanski junak sad pokazuje svu očinsku nježnost prema vlastitu čedu, koje je bilo zastrašeno (I 6,467-470) njegovim vojničkim izgledom:

"Odmah svijetli Hektor sa glave kacigu svoju

Sjajnu, presjajnu, skine i na tle je metne, te sina

Poljubi miloga svog i na rukama ponjiše njega"

(I 6,472-474)

Iz pjevanja se zna da je tome najprije prethodio skriveni, ali nježni, pogled upućen sinu (I, 6,404) dok ga je dojilja držala na grudima, potom Hektorov pokušaj da sebi privine 
DRUŠ. ISTRAŽ. ZAGREB GOD. 20 (2011), BR. $1(111)$

STR. 249-267

PRANJIĆ, M.: HOMEROVE ODGOJNE... čedo, a onda krik malenoga (I 6,466-468) poradi gorostasne i čudno odjevene pojave vlastita oca, na kojem je bila odora od mjedi, a kaciga s konjogrivinom resom (I 6, 469). Ovo kratko Ilijadino izvješće svjedoči o tome kako se grčki aristokrat i vojnik, onaj koga je resila vojnička vrlina, ponašao u trenutku zastrašenosti mladoga bića. Najprije mu je zajedno s majkom uputio osmijeh (I 6,471), davši mu do znanja da se ničega ne treba bojati kad su uz njega pored njegovateljice njegov otac i majka, potom je, znajući što je povod djetetova straha, skinuo kacigu s glave (I 6,472) mičući je izvan djetetova vidokruga, a onda cjelivao vlastito dijete i nježno ga njihao na rukama, dekoncentrirajući ga u njegovoj vizualnoj fikciji.

$\mathrm{Na}$ tako davnoj odgojnoj praksi, koja se stalno potvrđivala kroz povijest (Tenorth, 2008.; Christes i sur., 2006.; Böhm, 2007.; Depaepe, 1993.), i suvremene odgojne znanosti nastavljaju promicati slična ponašanja u trenutku odgajanikova straha: ljubaznost ključnih odgojnih faktora (otac, majka, odgajatelj!) koja se iskazuje na primjeren način, kroz mio pogled i ljubazan osmjeh kao prvi korak u suzbijanju straha, potom fizička i duševna blizina, što se manifestiraju tjelesnim kontaktom s preplašenim djetetom kako bi ga se lišilo straha i psihički rasteretilo (Scklafani, 2004.; Ennulat, 2001.; Grossmann, 1977.).

\section{ODGOJ DJEČAKA}

O ovoj temi postoje već vrijedna objavljena djela (Golden, 1990., 1997.; Neils i Beaumont, ur., 2003.; Pache, 2004.). Poštivanje roditelja bila je stroga dužnost o koju se djeca nisu smjela lako ogriješiti, a vježbalo se u djetinjstvu kako bi bilo stav i u zreloj dobi $(\mathrm{O} 2,130 \mathrm{~s})$. U protivnom trebalo se nadati prokletstvu vlastitih roditelja (O 2,135s), a i ljutnji samih bogova (O 2,131-136). Djeca, a iz poštivanja i odrasli, svoje su majke, barem one aristokratske, nazivali "gospođa majka" (I 6,429; 9,560). Dječaci su se najprije učili kućnim poslovima, a poslije junačkim i bojnim igrama i vještinama. Vladalo je uvjerenje da se kućnim poslovima postiže spretnost i domišljatost, koja je kasnije omogućavala snalaženje u svim životnim prilikama, pa i u samom ratu (O 2,314-316). Dijete je raslo uz roditeljsku brigu i skrb, pa i drugih ukućana, slušajući slatkorječiv govor bajki o bogovima, junacima, herojima vrijednim svakoga divljenja. Odrasli su nadasve imali na umu etički odgoj potomstva, ali nisu krili ni tajili ono što bi iz toga bilo vrlo važno i za njih same, naime, da u starosti nađu pomoć i zamjenu $(\mathrm{O} 19,368)$ te da se produži vijek vlastitu pokoljenju. Roditelji su čeznuli za tim da im djeca budu barem kao što su oni, štoviše, i bolja od njih samih: "Da rekne tko: 'od oca je taj valjaniji mnogo'" (I 6, 479). To što su Grci kućnom poslu pripisivali i odgojnu kvalitetu proizlazi iz Odisejevih riječi koje je kazao svinjaru Eumeju prije nego što mu se otkrio (O 14, 222-223). 
DRUŠ. ISTRAŽ. ZAGREB GOD. 20 (2011), BR. 1 (111)

STR. 249-267

PRANJIĆ, M. HOMEROVE ODGOJNE..
Kad je muškić postao dječakom, njegova se odgoja laćao otac vodeći ga sa sobom u društvo odraslih i postupno ga upućivao u životna znanja i umijeća. Koliko je to bila važna odgojna praksa, znano nam je, primjerice, iz Andromahina jadikovanja nad mrtvim Hektorom, gdje ona govori o predstojećoj sudbini sina Astijanaksa koji je ostao siroče nakon očeve pogibije, posvješćujući si ono što će se s njim događati kad bude tamo gdje je mjesto i njegovim vršnjacima, u društvu odraslih, ali bez očeve potpore:

"Zlopateći dolazi on prijateljima svojega oca,

Od njih za struku jednog, a drugog za košulju vuče;

Gdjekojem bude ga žao, pa vrčić dade mu mali,

Usne okvasi njim, al' ne može okvasit grla.

Dječak, što ima i oca i majku, od gozbe ga riva,

Rukama njega lupa i grdnim ga r'ječima psuje:

"Odlaz odavde, tvoj se među nama otac ne gosti."

Zaplakan onda se dječak udovici materi vraća, -

Sin naš Astijanaks, što prije na koljenima ocu

Jedaše samo mozak i ovnujsko debelo meso."

(I 22,492-502)

Što se iz ovih nekoliko redaka Ilijade može reći o starogrčkom odgoju dječaka? Ponajprije da je dojilja i nadalje imala važnu ulogu. Njezina se asistencija nije sastojala samo od hranjenja ( $\tau \rho \circ \varphi \eta$ ), premda je to bio prioritet kako bi se uopće moglo uzdizati čovjeka kao duhovno biće, nego i od najelementarnijih odgojnih zahvata koji su bili sinkronizirani s običajima i tradicijom obitelji te važnom ulogom majke. ${ }^{5}$ Nakon toga pak uslijedila je očeva sustavnija odgojna briga kad je riječ o dječaku, a majčina kad je riječ o djevojčici. Dječakov odgoj događao se, dakle, i ondje gdje se zbivao ne samo obiteljski nego i društveni život, gdje se raspredalo o ratnim vještinama, ali i o životu u mirnodopsko vrijeme, konkretno na simpozijima, ${ }^{6}$ o kojima govori i ovaj Ilijadin ulomak. Bila je to jedinstvena prilika za dječake da se u društvu svojih roditelja upoznaju s njihovim prijateljima te da se zbliže sa svima onima koji su imali društvenu težinu u ratu i u miru. Očevi, osim što su bili neposredni uzori i ideali svojoj djeci, pritom su bili i svojevrsni vodiči i posrednici. Zato već sad Andromaha žali nad svojim sinom, videći ga kako se mora zlopatiti (I 22,492) snalazeći se u tom nepoznatom, a opet tako uzvišenom i za životnu karijeru važnom društvu. Ono što bi dječak dobivao izravno od svog oca kao neposredno odgovornog za njegov odgoj u ovoj situaciji mora iskamčiti od prijatelja umiljavajući se, ponižavajući, vukući ih za rukave (I 22,493), a oni će mu se obraćati iz samilosti (I 22,494), tek toliko da zadovolje puku formu, od čega dijete neće imati velike koristi (I 22,494s). 
DRUŠ. ISTRAŽ. ZAGREB GOD. 20 (2011), BR. $1(111)$

STR. $249-267$

PRANJIĆ, M.: HOMEROVE ODGOJNE...
Iz ovoga se može zaključiti da je i antičkom Grku bilo sasvim jasno kako je odgajanje dugotrajno, sustavno zalaganje onoga u koga se ima povjerenje, koga se doživljava kao oslonac i ideal, odgajatelja koji svog odgajanika uči prve korake vodeći ga za ruku kroz život. Kad bi to imao Astijanaks, a neće imati, bi li se onda morao ponašati onako kako njegova majka već sluti? Zacijelo ne! Neće Astijanaks biti samo u tome prikraćen. On će istodobno osjetiti i to što znači živjeti u necjelovitoj obitelji kao važnoj odgojnoj agenciji za taj uzrast. Baš zbog toga bit će izložen fizičkom i psihičkom zlostavljanju svojih vršnjaka (I 22,496ss), a odgojna drama izražena kroz plač djeteta (I 22,499) bit će dovedena do duševne boli kad se spomene minula očeva nježnost i skrb (I 22,500-501).

Zdravi nježni odnos ${ }^{7}$ antički Grk - i muškarac i žena - nije pokazivao samo prema djetetu nego se on njegovao i prema odrasloj osobi u situacijama koje su to jednostavno pretpostavljale. Svojevrstan je to nastavak onog odnosa koji se instalirao u djetinjstvu. Toga ima poprilično u Homerovu djelu, osobito u Odiseji. Tako se, primjerice, odnosi Eumej (O 16,20$-26)^{8}$ prema Telemahu, kojeg je vidio nakon dugih godina izbivanja; tako se drži i Odisej u trenutku kad se otkriva Telemahu kao njegov otac (O 16,190-192); tako se ponašaju Telemah i otac mu u sličnoj situaciji (O 16,213-220), što će reći da je to bila redovita praksa i kad se nije štedjelo na nježnosti, premda je riječ o srčanom i ratničkom narodu.

Posebno se to pak vidi kod Odisejeva prvoga susreta sa sinom Telemahom nakon 20 godina lutanja po morima i Telemahove privrženosti u tom trenutku prema ocu $(\mathrm{O} 16,213 \mathrm{~s})$, odnosno međusobne nježnosti oca i sina (O 16,215-218), Penelopina ${ }^{9}$ dočeka potajno nestala jedinca. Razmotrit ćemo jedan po jedan od tih iskaza:

"Tako Odisej reče i poljubi sina, i njemu

Na tle se odroni suza od lica koju je dotle

Jednako pritiskivao: Telemah još vjerovat ne htje,

Da mu je otac to"

(O 16,190-193)

Nakon Telemahova povratka u vlastitu zemlju Itaku (O 15, 495-499) i dirljiva susreta sa slugom Eumejem (O 16,11-26),10 kako bi izbjegao za život prijeteći susret s proscima,11 a htijući doznati iz prve ruke situaciju u obiteljskom domu (O 16,31-35), naletio je na vlastita oca koji je bio prerušen u prosjaka tuđinca s Krete (O 6,57-63), a već nekoliko dana i sam gost kod sluge Eumeja. Spektakularni susret $(\mathrm{O} 16,173-179)^{12}$ s ocem odigrao se u Eumejevoj kolibi u trenutku dok je sluga bio na putu da odnese vijest Penelopi o Telemahovu povratku (O 16,130-131), ali ne i Odisejevu ocu Laertu (O 16,150s ). ${ }^{13}$ 
DRUŠ. ISTRAŽ. ZAGREB GOD. 20 (2011), BR. 1 (111)

STR. 249-267

PRANJIĆ, M. HOMEROVVE ODGOJNE..
Sinov šok je otac ublažio govoreći mu kako se ne treba plašiti, da on nije bog nego njegov otac zbog kojeg je puno propatio u životu od mnogih ljudi (O 16,181-183). Nakon toga uslijedio je upravo maločas doslovno navedeni tekst iz Odiseje, u kojem pisac kroz poljubac demonstrira nježnost oca prema sinu i samom stradalniku, zbog čega se nisu više mogle suspregnuti ni suze (O 16,191s), jer je prije kradomice doznao kroz kakve je sve nevolje moralo prolaziti njegovo dijete $(\mathrm{O}$ 16,91-94) i kako se u svemu ponašalo dostojno svojega roditelja $(\mathrm{O} 16,114)$. Zacijelo je Penelopa često spominjala sinu vrline i slavu njegova oca, koje je tako snažno podvukla u trenutku kad je prijetila opasnost vlastitu djetetu, i to onima koji su mu radili o glavi (O 4,724-728). Doslovno je riječ o starogrčkim antičkim "pedagoškim vrijednostima" kojim se kitio svaki vrli heladski aristokrat. Prije svega to je vrlina usvojena ne samo kao ideal nego kao unutrašnji stav (O 4,724s), potom junaštvo koje se može uspoređivati s onim lavljim $(\mathrm{O} 4,724)$, a onda i slava što se o njemu širila ne samo po rodnom Argosu nego po cijeloj Heladi $(\mathrm{O} 4,726)$, što će reći Grčkoj. Koliko su to bile važne, odnosno ključne, odgojne vrijednosti, svjedoči doslovno Penelopino ustrajavanje na njima (O 4,814-816). Nije onda čudo što je Telemah čeznuo da upozna takva oca, uzor i ideal, što je sve poduzeo, pa i to da je napustio vlastitu majku, dom, ugodno obiteljsko okruženje, relativno bezbrižan život ${ }^{14}$ kako bi došao do utjelovljenja onoga za čim je, bolje rečeno, za kim je i sam čeznuo. Onda i ne treba čuditi reakcija i jednoga i drugoga pri iznenadnom susretu: odgajatelja koji je postao svjestan da mu je odgajanik usvojio kreposti po kojima je sličan vlastitu ocu, unatoč njegovoj odsutnosti, a odgajanika što je pronašao ono čemu su ga stalno kroz život privikavali, od majke, preko slugu i sluškinja, pa sve do očevih prijatelja, da i sam bude neporočan, naime suze radosnice (O 16,214-220). Slično se ponašaju svi odgajatelji i odgajanici kad je u pitanju ideal.

Nije mogla drukčije reagirati ni Penelopa pri susretu sa svojim sinom, čiji joj je dolazak nagovijestio sluga Eumej, a iz kojeg ćemo ulomka također pokušati izvući "odgojna zrnca":

"Zaplače i svog milog obujmivši rukama sina,

Stane mu ljubiti glavu i obje lijepe oči;

Stane jaukat i ove progovori krilate r'ječi:

Tu li si, sunašce drago, Telemaše! vidjeti tebe

Više mislila nisam, otišao kako si u Pil"

(O 17,38-42)

Što je pak kod Penelope, Telemahove majke i Odisejeve supruge, prouzročilo takvu bujicu pozitivnih osjećaja? S jedne strane, zacijelo je to posljedica iznenadnoga bljeska ostvare- 
DRUŠ. ISTRAŽ. ZAGREB GOD. 20 (2011), BR. $1(111)$

STR. 249-267

PRANJIĆ, M.: HOMEROVE ODGOJNE... nja dugogodišnje nade da kao ožalošćena majka i supruga uz muža, svim vrlinama, junaštvom i slavom ovjenčana, neće ostati i bez sina jedinca. Što se dogodilo s njezinim sinom koji je $u$ ranoj mladosti, dok ga još nije mogao ni upoznati, ostao bez oca? Telemah je, naime, videći kako razulareni prosci ${ }^{15}$ njegove bez muža ostale majke, ${ }^{16}$ bezosjećajno troše njihovu imovinu, a ne mogavši to osobno spriječiti zbog svoje mladosti i nepostojanja adekvatnih "saveznika" te svjestan da mu u toj situaciji može pružiti pomoć samo otac, potajno je odlučio otići u potragu za njim. ${ }^{17}$ Krenuo je od Nelejeva Pila $(\mathrm{O} 3,4)$ gdje je živio kralj Nestor, ${ }^{18}$ sudionik Trojanskoga rata, od kojeg se Telemah nadao dobroj informaciji. Umjesto nje dobio je savjet $(\mathrm{O} 3,317)$ da o tome razgovara s Menelajem, ${ }^{19}$ spartanskim kraljem. K njemu Telemah dolazi s Nestorovim sinom. ${ }^{20}$ I uistinu, dok im obojici Menelaj pripovijeda o svojim pustolovnim dogodovštinama $(\mathrm{O} 4,82-85)$ i ratničkim doživljajima, iznenadno je spomenuo Odiseja, koji je pretrpio i podnio muka kao ni jedan drugi Ahejac (O 4.104-105), iskazujući zbog toga žaljenje njegovoj supruzi Penelopi i malahnom sinu Telemahu (O 4,107.111). Menelaj nije znao da to govori pred samim Telemahom. Potom je kazao ono čega se ponajviše pribojavao Odisejev sin, naime to da o njegovu ocu osobno ništa ne zna $(\mathrm{O} 4,109)$, ne zna je li živ ili mrtav $(\mathrm{O} 4,110)$, da zna kako se još nije vratio svome domu $(\mathrm{O} 4,109)$ i da zbog toga on, njegov ratni drug, neizmjerno pati $(\mathrm{O} 4,104)$.

Zanimljivo je koji povod Telemahovu dolasku Menelaju navodi njegov prijatelj Pisistrat. Ono, naime, što je bila srž starogrčkog odgoja: "ne bi li riječ ga ti naučio koju il' djelo" Ö $\varphi \rho \alpha$ oi like dolazilo u opasnost kada bi otac kao glavna okosnica dječakova odgoja bio odsutan (O 4,164-167). Upravo je tako bilo kod Telemaha. Ni on u djetinjstvu nije imao oca koji bi ga učio riječi i djelu $(\mathrm{O} 4,205)$, kako bi mogao biti nasljednik takva oca $(O 4,206)$ i u njemu prepoznavati ideal što se usađuje u odgajanika od rođenja pa sve do punoljetnosti (O 4,207-208).

Vratimo se nakon ovoga opširnijeg uvoda kako bi se razumio kontekst odgojnim zrncima Penelopina ushita. On je, dakle, posljedica povratka sina Telemaha nakon potajnoga nestanka i dugogodišnje odsutnosti, a s nakanom da pronađe svog oca, ideal i uzor svakom djetetu, te da si osigura pomoć $\mathrm{u}$ razračunavanju s majčinim proscima. Suze radosnice popraćene su daljnjim iskazom nježnosti: obimanjem $(\mathrm{O}$ 17,38), ljubljenjem glave i očiju $(\mathrm{O} 17,39)$, upotrebom probranih riječi (O 17,41), što sve skupa, i danas nakon više od tri tisuće godina koliko je star ovaj izvještaj, predstavlja vrijednosti koje se manifestira u trenutku susreta roditelja s djetetom nakon duga izbivanja, a ondje gdje je odgoj omogućio blizak odnos od- 
DRUŠ. ISTRAŽ. ZAGREB GOD. 20 (2011),

BR. 1 (111)

STR. 249-267

PRANJIĆ, $M$.

HOMEROVE ODGOJNE.. gajatelja i odgajanika. U prvom su planu, dakle, "odgojne radnje" koje stvaraju, a potom i trajno zadržavaju, povjerenje, blizinu, privrženost, vjernost. Da u Telemahovu djetinjstvu toga nije bilo, da se njegov najuži obiteljski krug prema njemu nije tako odnosio kao djetetu, a i on prema svojima, teško bi to sad bilo upriličiti.

\section{ODGOJ MLADIĆA}

O ovome postoji dobra literatura (Clarke, 1971.; Cribiore, 1996.; Ducat, 2006.; Forbes, 1929.; Kleijwegt, 1991.). Idemo na jednom primjeru pokazati neke elemente odgajanja mladića kod Homera. Iz devetoga pjevanja Ilijade sasvim je razvidno da je Feniks bio odgajatelj Ahileja kao mladića, što uostalom sam Feniks spominje Ahileju dok ga nagovara da se vrati u grčke čete i pomogne Agamemnonu i cijeloj njegovoj vojsci ovladati gradom Trojom, njezinim kraljem Prijamom i cijelom njegovom obitelji. Feniks podsjeća Ahileja na davne dane kad ga je njegov otac Pelej iz Ftije uputio Agamemnonu zajedno s njegovim odgajateljem Feniksom, a dok još nije bio vičan ni ratu, a ni životu u narodnom zboru (skupštini!), pa mu je zato pridružio odgajatelja kako bi ga učio svemu što je potrebno za život. Evo tih riječi:

"Ta Pelej starina konjanik s tobom

Posla i mene onda, kad spremaše iz Ftije tebe

On Agamemnonu luda, još ni rata n'jesi poznavo

Jednako krvavoga ni skupština, gdje se veoma

Proslave ljudi, pa zato i posla mene, da učim

Sve to tebe, da budeš govornik i radiša dobar."

(I 9, 438-444)

Što se može s pedagoškoga stajališta iščitati iz ovih nekoliko redaka 9. pjevanja Ilijade? Prije svega da je u staroj Grčkoj imućna obitelj, kakva je bila i ona Pelejeva, imala za svoju dje$\mathrm{cu}$, osobito mušku, posebnog učitelja, odgajatelja, ( $\pi \alpha \iota \delta \alpha \gamma \omega \gamma o ́ \varsigma)$ koji je svoga štićenika pratio kamo god je to trebalo, a osobito kad bi išao nekome na pouku, što je i ovdje slučaj dok mirmidonski kralj Pelej šalje mladog Ahileja, svoga sina, vojskovođi Agamemnonu "u školu" kako bi ga ovaj poučio u krvavim ratnim vještinama i u aktivnom sudjelovanju u vojnim skupštinama, koje su pružale jedinstvenu priliku za stjecanje slave do koje je bilo vrlo stalo svakom starogrčkom pripadniku plemenitaške obitelji. Ovdje Feniks spominje Ahileju da ga je on $\mathrm{u}$ svemu tome trebao učiti. No to zapravo nije prava istina.

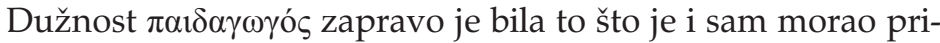
sustvovati "nastavi" kako bi "učenika" mogao na putu do "škole" i od nje vježbati u onom što je dijete u njoj čulo i naučilo. Konkretno, radi se o nečemu što je nadilazilo Feniksove "uči- 
DRUŠ. ISTRAŽ. ZAGREB GOD. 20 (2011), BR. $1(111)$

STR. 249-267

PRANJIĆ, M.: HOMEROVE ODGOJNE... teljske kvalifikacije", naime, o vježbanju u ratničkim krvavim vještinama i aktivnom sudjelovanju $u$ vojničkim skupštinama, što je dobro poznavao Agamemnon, ahajski kralj i vojskovođa, a ne Feniks.

Jedanaesto pjevanje Ilijade, dok pak govori o Patroklu kao Ahilejevu učeniku, spominje kako je Ahileja poučavao i Hiron, ali ovaj u liječničkom umijeću. Śto će reći da je i učenik u antici imao više učitelja, već prema tome što je trebao i tko je to dobro znao. Evo navoda iz Ilijade:

"Nego me spasi ti, o Patroklo, i k lađi crnoj

Mene odvedi i str'jela iz bedra mi izreži i krv

Mlakom mi vodom isperi i l'jekove blage i dobre

Metni mi, što te je, kažu, naučio divni Ahilej,

A njeg nauči Hiron od sviju Kentaura bolji."

(I 11,828-832)

Jasno, u prvom redu riječ je o Patroklu kao Ahilejevu učeniku, gdje se pak spominje i to kako je liječničko umijeće Patroklo naučio ne samo od Ahileja nego i od Ahilejeva učitelja Hirona. To svjedoči ranjeni vitez Euripil (I, 11,809; 819), koji je zacijelo poznavao Patroklovu liječniku izvrsnost i koja je očito bila poznata ostalim grčkim suborcima, pa ga stoga usrdno moli da mu priskoči u pomoć: da ga odvede na mirno i sigurno mjesto (u lađu!), da se ratnička strijela iz tijela nije vadila nego "izrezivala", da se krv nije ispirala bilo kakvom nego mlakom vodom kako bi se potom na ranu stavljalo "blage i dobre" lijekove, a ne "ljutu travu na ljutu ranu", što bi možda tko mogao pomisliti kad je riječ o grčkim junacima. U ovom trenutku Euripil spominje informaciju o Patroklovoj liječničkoj vrsnoći, o kojoj je on čuo od drugih, naime, da postoji više odgajateljskih koljena njegova liječničkog umijeća. Najmlađe potječe od njegova učitelja Ahileja, ali ono starije od učitelja njegova učitelja, od samog Hirona Kentaura. Drugim riječima, Ahilejevi učitelji, može se zaključiti iz ovoga, bili su najprije Feniks, potom Agamemnon, ali i Hiron. Prvi mu je prenio elementarni odgoj kroz ljubav, tako što ga je držao na svojim koljenima tažeći njegovu glad i žeđ, ne mareći za dječje propuste i tako kod njega stvarao osjećaj voljenosti, što je bila osnova za kasnije ratničko samopouzdanje. Drugi ga je učio ratničkim vještinama privikavajući ga na okrutnost te djelatnostima vezanima uz nastup i uvjeravanje sugovornika $\mathrm{u}$ skupštinama ratnika, dok mu je treći nudio znanja koja su mogla biti presudna za nastavak vlastita život i života njegovih suboraca, ona liječnička.

Vratimo se ponovno prvom Ahilejevom odgajatelju, Feniksu. Po sebi je pomalo dramatična povijest Feniksa, Amintorova sina (I 9,448s). U mladosti se sukobio s vlastitim ocem 
DRUŠ. ISTRAŽ. ZAGREB GOD. 20 (2011), BR. 1 (111)

STR. $249-267$

PRANJIĆ, M. HOMEROVE ODGOJNE... kad ga je njegova majka uplela u očevu ljubavnu vezu kako bi ljubavnici omrznula svoga bračnog druga. Majčina je želja bila, budući da ju je muž Amintor zbog ljubavničke veze prezirao i zapostavljao, da ga vrati. Kad je otac doznao za tu igru, prokleo je Feniksa tako da mu na koljena kao djedu nikad ne sjedne Feniksov potomak (I 9,455 ss), što su bogovi i uslišali, a kod Feniksa to je stvorilo toliki gnjev da ga je namjeravao ubiti vlastitim rukama. No bojeći se ljudskoga prezira, a i straha da će biti prozvan "ocoubilcem" (I 9,461), nije to učinio. Međutim, zbog te konfliktne situacije nije mogao više ostati u roditeljskom domu, usprkos molbama i zadržavanja rodbine, nego je jednom prilikom pobjegao od kuće i skrasio se u Ftiji kod Peleja, Ahilejeva oca. U novom domu naišao je na dobrodošlicu i ponovno otkrio svoj mir. Gospodar ga je učinio bogatim, štoviše, postao je njegovim vazalom, knezom ( I 9,485), te uz to i odgajateljem gazdina mladog potomka Ahileja.

Malo dalje Feniks podsjeća svog odgajanika Ahileja kako ga je od srca ljubio (I 9,486), a ovaj zauzvrat, dok je bio malen, nije htio biti ni s kim drugim doli s njim; da nije htio jesti dok ga Feniks ne bi stavio na koljena; da ni od koga drugoga nije htio uzeti vina doli od njega; da sam nije ništa mario kad bi mu dijete po košulji prolilo vino i t.d. (I 9,486s.). Sve kvalitete vrlo privržena i skrbna odgajatelja koga je odgajanik prihvatio kao svoga, ${ }^{21}$ ali i odgajatelj njega. No nakon nabrajanja pozitivnih "odgojnih vrlina" Feniks podsjeća i na onu drugu stranu odgoja, kazavši: "tako se napatih mnogo i izmučih okolo tebe" (I 9,492-494).22

Feniks u svom prisjećanju podvlači vrlo važnu komponentu odgoja, naime, tu da je odgajanje uz ostalo i teret, obveza, patnja, a ne samo lagoda i ugoda. Odgoj pretpostavlja angažman, koji često graniči, štoviše, poistovjećuje se, sa žrtvovanjem samoga sebe, pa i stupnja empatije koja sliči na posinjenje odgajanika, iako mu je još uvijek živ roditelj. Usprkos svemu ili upravo zbog toga, morao je to biti krasan osjećaj vlastita odgojnog uspjeha kad Feniks završava svoj sud o svojoj davnoj odgojnoj djelatnosti tvrdnjom: "Ahileju bozima slični". Što je mogao dobiti kao nagradu ili: što je više mogao očekivati starogrčki odgajatelj od svoga odgojnog angažmana doli da mu na koncu odgajanik izgleda božanskim, bogolikim, bogu sličnim?! Ne nazire li se već ovdje ono što će kasnije Platon nazvati "svijetom ideja" koje postoje zasebno, od vječnosti, koje su svijet ideala u "onostranosti", a s kojima će se uspoređivati svaki ljudski lik i težiti svaka ljudska djelatnost?! Zacijelo Ahilej to nije mogao nikako biti da je slučajno uzmanjkala prva ljubav, a onda i sustavna skrb oko njega kad je trebao toplu riječ, pomoć, prihvaćanje, praštanje kako bi se raslo u samopouzdanju i prihvaćanju sebe kao prepoznatljive vrijed- 
DRUŠ. ISTRAŽ. ZAGREB GOD. 20 (2011), BR. $1(111)$

STR. 249-267

PRANJIĆ, M.: HOMEROVE ODGOJNE... nosti zbog koje je kasnije kao junak bez premca bio prepoznat i prihvaćen i od svojih suboraca. Podlogu je stvorio Feniks, njegov najraniji odgajatelj.

Koliki je utjecaj kod starih Grka pojedini odgajatelj imao na svog odgajanika vidi se upravo iz Ilijadina 9. pjevanja kad Feniksa, Ahilejeva odgajatelja, skupština vojske postavlja na čelo povjerenstva koje se upućuje Ahileju kako bi ga se privoljelo na pomirenje s Agamemnonom. Njega se stavlja u društvo s Ajasom i Odisejom (I, 9,168s). Prvi je Ahilejev stričević, ahejski junak koji je u lađama doveo vrsne čete bojovnika s otoka Salamine pod Troju i tako znatno pridonio ratničkoj snazi Grka, dok Odisej pripada prvim grčkim junacima u tom sudbonosnom ratu zbog svoje hrabrosti, ali i svoje domišljatosti. U tom i takvom društvu najboljih ahejskih junaka i Ahileju najdražih Argejaca (I, 9,520ss) Feniks nije mogao biti doli i sam junak i vitez (I 9,485), što je on uistinu i bio kao Pelejev vazal. Stoga je očito da je ovdje odgajateljev lik Feniksa u uskoj vezi s "odgojnim idealima" druge dvojice poslanika, od kojih Ajas više utjelovljuje djelo, dok Odisej riječ, te na taj način manifestiraju i do ideala sublimiraju onu Feniksovu tvrdnju "da budeš govornik i radiša dobar" (I 9,443). Drugim riječima, kao što to sad izgleda u Feniksovim očima kad pred sobom ima cjelovita i profilirana heroja, $u$ Ahileju je objedinjeno oboje, došlo je do nevjerojatne usklađenosti duhovnih i djelatnih kvaliteta, pa se stoga Feniks može nadati da njegov apel za promjenu Ahilejeva stava naspram Agamemnonu može imati učinka (I 9,496ss), jer takvih primjera ima mnogo u grčkoj prošlosti (I 9,524ss), primjerice onaj Meleagerov, iako se to nije zbilo tako brzo kod Ahileja pa se ovaj oblik govora može shvatiti tek kao "uzorak odgajateljeva protrepskog nagovora njegovu odgajaniku" (Jaeger, 1989., 52) kao tipična oblika poučna govora. Samo se tom usporedbom u ovom slučaju mogao koristiti Feniks, koji je s pravom računao na Ahilejevu odanost, dok bi kod druge dvojice članova poslanstva tako nešto moglo izazvati samo još veće zaoštravanje sukoba. $U$ toj dramatičnosti nazire se etički i odgojni obrat, unutar kojega pravedna srdžba sve više pritišće u smjeru svijesti gdje se raspliće sukob o kojem ovisi sudbina Grka, ali i Ahilejeva sloboda, a tiče se s jedne strane molbi, a s druge okorjelosti ljudskoga srca.

Na taj način pjesnik je u Feniksovu liku samom odgoju postavio visok spomenik, kojemu se on, uostalom, divi, ali iz kojeg proizlazi i Ahilejeva sudbina kao posljedica plemenitaškog odgoja unutar kojeg se kristale muževne kreposti, ali i zaslijepljenost "pravednom srdžbom" kao iracionalnom moći koja može stati na put cjelovitu odgoju. Zato je pjesnik i utjelovljenje molbi koje su namijenjene ljudima, doduše sporih, 
DRUŠ. ISTRAŽ. ZAGREB GOD. 20 (2011) BR. 1 (111)

STR. $249-267$

PRANJIĆ, $M$. HOMEROVE ODGOJNE..

\section{UZOR I ETIKA}

ali u stanju da poprave štetu što ih prouzroči ljutnja. Pjesnik taj čovjekov unutrašnji svijet predstavlja religioznim simbolima. S jedne je strane božica Ate, kao personifikacija obmane, a s druge su božanske moći molbe, bolje rečeno, molitve, koje su spore i vuku se polako iza nje, no ipak su i kao takve Zeusove kćeri koje treba častiti jer prijateljski pomažu čovjeku. U suprotnom, ako ih čovjek odbaci, dolazi Ate koju se može umiriti tek vrlo zahtjevnim otkupninama.

Riječ je zapravo o predodžbi dobrih i zlih demona, dobra i zla kao takvog, a koja još nije dotakla razinu apstrakcije, no zato ne manje očite za otimanje oko ljudskoga srca, odnosno nutarnjega sukoba strasti i znanja kao središnjega odgojnog problema. Jasno da bi se u ovaj odgojni koncept teško mogao uključiti suvremeni pojam slobodnog odgoja kao i svojevrsna krivnja u tom smislu. Starija odgojna misao u tom je tragičnija, a ljudski ulog dramatičniji, što se, uostalom, vidi iz Homerovih epova. No praktični starogrčki plemenitaški odgojni stav ovdje se kristali u svom najstarijem i najljepšem izvoru osvješćujući probleme granica ljudskoga odgoja.

Iz literature je znano da je u Homerovo vrijeme uzor imao vrlo važnu ulogu u životu (Beck, 1975.; Barclay, 1959.; Barrow, 1976.; Blanck, 1992.). Govor o čovjeku nije tek izraz puke mašte, niti je samo odraz tadašnjega načina života, nego predstavljanje obveznog utjelovljeno u tom i takvom čovjeku. Na taj način pjesnik želi biti odgajatelj svoga naroda (Marrou, 1977.) i u punom smislu riječi on je i postao odgajatelj cijele Grčke: $\tau \eta^{\prime} v$ 'E $\lambda \lambda \alpha \dot{\delta} \alpha \pi \varepsilon \pi \alpha i ́ \delta \varepsilon v \kappa \varepsilon v$ (ten Helada pepaideuken); stoljećima je bio odgajatelj i mnogih drugih naroda. Njegova je Ilijada za Grke istodobno i teogonija i teodiceja i apologetika, štoviše, vademecum praktičnoga moralnog ponašanja (Marrou, 1977.). Rijetko je koji ep imao tako velik i širok utjecaj na čovječanstvo kao što je to bilo s Homerovima, počevši od antike pa sve do današnjih dana (Marrou, 1977.; Jaeger, 1989.; Wilamowitz, 1920.). Dovoljno je misliti samo na to kako je već u 8. st. pr. Kr. utjecao na Hesiodov stil, na Aleksandra Velikog, na bizantski rani srednji vijek, koji se dobrano nadahnjivao tim istim Homerom (Marrou, 1977.).

Homer je vrstan interpretator viteške etike, koja je bila središte, ideal, grčkog odgoja (Lechner, 1933.). Stoga nemaju pravo oni koji u njegovu opusu gledaju samo literarno djelo. Ono je i etički priručnik, obris grčkoga odgojnog ideala. To se vidi i po tome što se tehnička strana grčkog odgoja kroz povijest znatno, pa i temeljito, mijenjala, dok je homerovska etika znala tomu i odolijevati (Lechner, 1933.). Tako su i pojedini naknadni pedagozi, da bi opravdali i utemeljili svoje pedagoško razmišljanje, posezali za Homerom i u njemu tražili e- 
DRUŠ. ISTRAŽ. ZAGREB GOD. 20 (2011), BR. $1(111)$

STR. 249-267

PRANJIĆ, M.: HOMEROVE ODGOJNE... lemente za vlastito vrijeme religioznih i moralnih normi (Hacks, 1997.; Shay, 1998.; Parker, 2001.; Jaeger, 1989.). Pretvarali su njegovo djelo u neku vrstu grčkoga odgojnog katekizma, popisa obveza naspram bogova, životnoga pratioca praktičnoga morala koji je objašnjavao pojedine zapovijedi i na umu imao lijepo ponašanje.

Glavno Homerovo odgojno uporište ležalo je u njegovu načinu tretiranja heroja, u njihovu etičkom modeliranju (Schmid, 1892.), životnom stilu, što je dugom upotrebom i čitanjem njegova djela znatno utjecalo na čitatelje, pa otuda i dosta opravdana utemeljenost da se s razlogom može govoriti o "home-

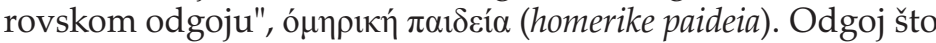
ga je mladi Grk crpio iz Homera bio je odgoj koji je pjesnik pripisivao svojim junacima, a zapravo je riječ o umijeću preživljavanja u svakoj situaciji. Moralni ideal savršena Homerovoga viteza izriče se pojmom junačke časti, ljubavi do slave koja ne uzmiče pred kratkoćom života, prijetnjom smrti ili oskudnoj utjesi koja se nudi iz onostranosti.

"Nemoj, Odiseju dični, što umrijeh, tješiti mene;

jer bih volio biti i tèžâk i služiti drugom

Koji svojega nema imetka te od mala živi,

Negol' mrtvacima vladat, sa zemlje što no ih nesta."

(O 11,488-489)

Homerovi junaci žarko ljube upravo taj i takav kratki život, što ga njegova izloženost čini još riskantnijim. Ljube ga zemaljskim srcem, ljubavlju bez primisli, pa ipak samo življenje života nije najveća vrijednost kojoj oni teže i kojom bi htjeli raspolagati. Oni su ga voljni i spremni žrtvovati zbog drugog ideala, zbog časti. Homerova etika jest etika časti. Upravo ta svijest i nutarnji stav učinili su da su mnogi Homerovi junaci išli u smrt uzdignute glave. Nije bila toliko riječ o tome da se žrtvuje za domovinu, koliko da se stekne čast. Zbog vlastite časti Ahilej se odlučio na takav put, zbog nje je i Odisej podnosio sve što je podnio, ali i Penelopa, što ju je držalo uzvišena čela $u$ vrlo teškim i mučnim situacijama. Biti prvi, biti pobjednik, nadvisiti, nadjačati drugoga, ostvariti herojski čin

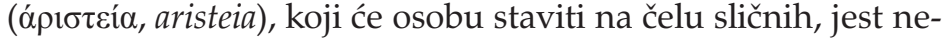
što za što se živi i za što se umire.

Homerov junak utjelovljuje u svom životu i u svojoj smrti konkretan ideal, određen način življenja koji je sadržan u pojmu ó $\rho \varepsilon \tau$ (Marrou, 1977.). Slava, reklo bi se, popularnost, što se širi oko junaka, jest mjera, objektivno priznanje same vrhunske vrijednosti (Meyer, 1947.). Odatle i strastvena želja za njom, želja da se bude oslovljavan kao najbolji. Upravo je to najskriveniji i najintimniji poriv viteške etičnosti (Eucken, 1921.). Homerov je junak samo onda sretan kad se osjeća prvim u svojoj kategoriji, drukčiji od drugih, bolji od svih njih (Meyer, 1947.; Eucken, 1921.). Njegova osnovna pedagoška 
DRUŠ. ISTRAŽ. ZAGREB GOD. 20 (2011), BR. 1 (111)

STR. 249-267

PRANJIĆ, M.: HOMEROVVE ODGOJNE...

ideja jest: "Vazda nek najbolji budem i odličan između drugih

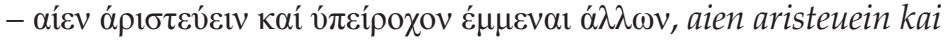
hipeirohon emenai alon" (I 6,208).

Iz te ideje slave proizlazi i odgojna uloga pjesnika Ilijade i Odiseje (Gschnitzer, 1999.; Lesky, 1952.; Wilamowitz, 1920.). Cilj na koji je usredotočeno njegovo djelo nije čisto estetske naravi nego se sastoji od toga da se heroje učini besmrtnima, pa će stoga Platon kazati da je Homer nebrojena junačka djela starih okitio slavom i tako odgajao potomstvo (Jaeger, 1989., 1). Savjetima Homer nudi svojim čitateljima velike uzore i primjere koji u njima pobuđuju borilački instinkt, želju za natjecanjem:

" ... prilično nije

Tebi da djetinjiš još, kad nisi takove dobi

Ne znaš li, kakva je slava Oresta zapala divnog

Među ljudima svim, što ubilca očeva smače,

Podmuklog onog Egista, što oca mu dičnoga ubi?

I ti se, prijane, daj ojunači, - jer vidim te krasna,

I visoka te vidi, - da jednoć te hvale potomci"

(O 1,296-302)

Tajna homerovskog odgoja jest herojski primjer, $\pi \alpha \rho \alpha ́ \delta \varepsilon \imath \gamma \mu \alpha$ (paradeigma), ono što bi srednjovjekovni ljudi nazvali "imitatio", tako da su mnogi Grci naučili od Homera prezirati dug i bogat život samo kako bi se domogli herojske slave, bila ona ne znam kako kratka! To je Homera učinilo nepokolebljivom osnovom klasične pedagoške tradicije, pa i onda kada je bilo pokušaja da se uzdrma njegov svemoćni utjecaj i kontinuitet te tradicije.

Na kraju ovog istraživanja može se bez daljnjega ustvrditi da Homerovo djelo, premda prije svega i eminentno književno, ipak krije u sebi i mnogo odgojnih elemenata, zbog čega je opravdano i sasvim utemeljeno i njegovo "pedagoško iščitavanje", koje pedagogiji kao znanosti nudi neprijeporna pedagoška načela, a pedagoškoj praksi kontinuitet što iza sebe ima tisućljetnu povijest, pa zbog toga i određenu sigurnost da se sa sličnom može nastaviti i u vremenu kriza i osporavanja. To ni u kojem slučaju ne isključuje mogućnost razmišljanje o diskontinuitetu - i na području pedagoške načelnosti i odgojne prakse - čemu bi pojedine odgojne ideje u Homeru zacijelo dale sasvim dovoljnu razložnost. No to je nov problem koji bi u svakom slučaju bilo hvalevrijedno obraditi.

\section{BILJEŠKE}

1 Zbog ekonomiziranja prostora "I" znači Ilijada, a "O" Odiseja. Navodi iz Ilijade i Odiseje slijede hrvatski prijevod Homerova djela: Homer, Ilijada, preveo i protumačio Maretić, T., pregledao i priredio Ivšić, S., Zagreb 2003., Nakladni zavod Matice hrvatske, te Homer, Odiseja, preveo i protumačio Maretić, T., pregledao i priredio Ivšić, S., 
DRUŠ. ISTRAŽ. ZAGREB GOD. 20 (2011), BR. $1(111)$

STR. 249-267

PRANJIĆ, $M$ : HOMEROVE ODGOJNE...
Zagreb 2003., Nakladni zavod Matice hrvatske, uz redovitu usporedbu s prijevodom istog djela na njemački jezik: Giebel, M., ur. (2009.) Homerus Odyssee, Übers. Voß, Johann Heinrich, Augsburg: Weltbild i Homerus Ilias (2002.), in der Übertragung von Johann Heinrich Voß, München: Dt. Taschenbuch-Verlag kao i praćenje teksta u originalu prema: Dindorf, G. (1896.), Homeri Ilias, Leipzig, B. G. Teubner, odnosno Ameis, F., ur. (1865.), Honmers Osdysee, Leipzig: B. G. Teubner.

2 Homer samo na jednom mjestu možda spominje pismenost $u$ Heladi: I 6,168-169.

3 Dovoljno je imati pred očima neke osobe iz Ilijade i Odiseje, poput Ahileja, Eurikleje, Nausikaje, Andromahe, Telemaha, Penelope itd.

4 Ima mnogo primjera o tome $u$ Homerovu djelu. Ovdje donosimo samo jedan.

5 Usp. prikaze Andromahe i Penelope i njihov odnos prema vlastitoj djeci - Astijanaksu i Telemahu.

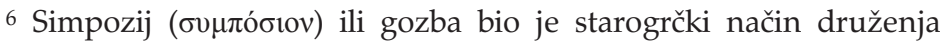
odraslih ljudi sa svečanim tonom koji je, pogotovo u kasnijim vremenima, katkad znao završiti i pijankom. Na njemu su sudjelovali muškarci u pratnji svojih supruga, a vodili su sa sobom i muško potomstvo. Simpozij će u mlađoj grčkoj povijesti poprimiti i značenje književne vrste, odnosno podvrste dijaloga unutar kojeg se partneri zamišljaju sudionicima gozbe. Rasprava se, kroz pitanja i odgovore, vodi oko središnjega problema, a usput se diskutira o raznovrsnim temama. Postoje sačuvani gozbeni dijalozi Platona, Ksenofonta, Plutarha, Ateneja i Makrobija.

7 Osim toga, stari Grci, ali ne iz Homerova vremena, poznavali su i paiderestiju ( $\pi \alpha 1 \delta \varepsilon \rho \varepsilon \sigma \tau i ́ \alpha)$, koja je imala mnoga obilježja suvremene pedofilije (usp. Platon, Gozba, 181c; 192b). No nisu je tako i toliko žigosali kao danas.

8 Eumej je bio svinjar u Odisejevoj obitelji, silno vezan uz svoga gospodara, ali privržen i njegovu sinu te Penelopi.

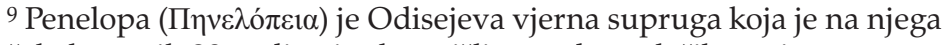
čekala punih 20 godina i vrlo smišljeno odugovlačila svoju ponovnu udaju. Njezine smicalice su joj omogućile doček muža.

10 I ovdje ima puno odgojnih elemenata koji manifestiraju odnos sluge prema gospodarevu djetetu, ljubavi koja je nastala tijekom zajedničkog suživota i međusobne empatije.

11 Ubojstvo Telemaha je nagovješteno već znatno ranije (O 4,845-847).

12 Naime, Atena je u tili čas prosjaka što ga je malo čas prije upoznao Telemah pretvorila u naočita i dobro obučena muškarca za koga je Telemah pomislio da je sam bog.

13 Njemu je o tome vijest trebala javiti ključarica Eurikleja (O 16,152s).

14 Pod uvjetom da je mogao prihvatiti rasipništvo prosaca i pomiriti se s tim da i njega i majku mu dovedu na zao glas.

15 Riječ je o 108 udvarača koji su je salijetali 20 godina.

16 Odisej je nakon desetogodišnjeg Trojanskoga rata lutao još deset godina po morima, izgubio sve prijatelje prije nego što se vratio na Itaku. 
DRUŠ. ISTRAŽ. ZAGREB GOD. 20 (2011), BR. 1 (111),

STR. 249-267

PRANJIĆ, $M$. HOMEROVE ODGOJNE..

\section{LITERATURA}

17 Svoju nakanu otkrio je samo Eurikleji, Odisejevoj dojilji, a sad ključarici u njegovu domu (O 2,345; 356-358).

${ }_{18}$ Nestor je bio poznat po dobrim savjetima i zato nije bez razloga što s njim prvim želi razgovarati Telemah o svom ocu Odiseju.

${ }^{19}$ Spartanski kralj, brat mikenskoga kralja Agamemnona, čiju je ženu Helenu oteo Paris, trojanski princ, što je bio povod Trojanskom ratu.

${ }^{20}$ Riječ je o Pisistratu $(\mathrm{O} 3,482)$.

21 Štoviše, izrijekom kaže da ga je posinio.

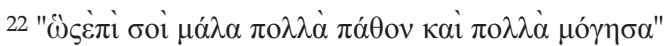

Ameis, F. (ur.) (1865.), Honmers Osdysee, für den Schulgebrauch, Leipzig: B. G. Teubner.

Ariès, Ph. (2003.), Geschichte der Kindheit, München: Dt. Taschenbuch-Verl.

Barclay, W. (1959.), Educational Ideals in the Ancient World, London: Collins. Barrow, R. (1976.), Greek And Roman Education, Basingstok: Routledge. Beck, F. A. G. (1975.), Album of Greek Education, Sydney: Frederick A. G. Blanck, H. (1992.), Das Buch in der Antike, München: Beck.

Böhm, W. (2007.), Geschichte der Pädagogik von Platon bis zur Gegenwart, München: Beck.

Christes, J., Klein, R. i Lüth, Ch. (2006.), Handbuch der Bildung und Erziehung in der Antike, Darmstadt: Wissenschaftliche Buchgesellschaft.

Clarke, M. (1971.), Higher Education in the Ancient World, London: Routledge.

Cribiore, R. (1996.), Writing, Teachers, and Students in Graeco-Roman Egypt, Atlanta: Scholars Press.

Depaepe, M. (1993.), Zum Wohl des Kindes? Pädologie, pädagogische Psychologie und experimentelle Pädagogik in Europa und den USA, 1890 - 1940, Weinheim: Dt. Studien-Verlag.

Dindorf, G. (ur.) (1894.-1896.), Homeri Ilias, pars I-XII i pars XIII-XXIV, editio stereotypa, Leipzig: B. G. Teubner.

Ducat, J. (2006.), Spartan Education: Youth and Society in the Classical Period, Swansea: Classical Press of Wales.

Ennulat, G. (2001.), Ängste im Kindergarten ein Praxisbuch für Erzieherinnen und Eltern, München: Kössel.

Eucken, R. (1921.), Die Lebensanschauungen der großen Denker, Berlin: de Gruyter.

Forbes, C. A. (1929.), Greek Physical Education, New York: Century Co. Freemans, K. J. (1932.), Schools of Hellas, London: Macmilan.

Giebel, M. (ur.) (2009.), Homerus Odyssee, Übers. Voß, Johann Heinrich, Augsburg: Weltbild.

Golden, M. (1990.), Children and Childhood in Classical Athens, Baltimore: Johns Hopkins Univ. Press. 
DRUŠ. ISTRAŽ. ZAGREB GOD. 20 (2011), BR. 1 (111)

STR. 249-267

PRANJIĆ, $M$ : HOMEROVE ODGOJNE..
Golden, M. (1997.), Change or Continuity? Children and Childhood in Hellenistic Historiography. U: M. Golden i P. Toohey (ur.), Inventing Ancient Culture: Historicism, Periodization, and the Ancient World (str. 176-191), London: Routledge.

Grossmann, K. (1977.), Angst und Lernen. Angstfreie Erziehung in Schule und Elternhaus, München: Kindler.

Gschnitzer, F. (1999.), Homer. U: K. Brodersen (ur.), Grosse Gestalten der Griechischen Antike. 58 Historische Portraits von Homer bis Kleopatra (str. 12-21), München: Beck.

Hacks, P. (1997.), Prinz Telemach und sein Lehrer Mentor, Berlin: Eulenspiegel-Verlag.

Homer (2003.), Ilijada, preveo i protumačio Tomo Maretić, pregledao i priredio Stjepan Ivšić, Zagreb: Nakladni zavod Matice hrvatske.

Homer (2003.), Odiseja, preveo i protumačio Tomo Maretić, pregledao i priredio Stjepan Ivšić, Zagreb: Nakladni zavod Matice hrvatske.

Homerus Ilias (2002.), In der Übertragung von Johann Heinrich Voß, München: Dt. Taschenbuch-Verlag.

Jaeger, W. (1989.), Paideia. Die Formung des griechischen Menschen 1-3, Berlin-New York: de Gruyter.

Kleijwegt, M. (1991.), Ancient Youth: The Ambiguity of Youth and the Absence of Adolescence in Greco-Roman Society, Amsterdam: Gieben.

Ksenofont (1898.), Ksenofonovi izabrani spisi, Zagreb: Matica hrvatska.

Lechner, M. (1933.), Erziehung und Bildung in der griechischen und römischen Antike, München: Hueber.

Lesky, A. (1952.), Die Homerforschung in der Gegenwart, Wien: Sexl.

Marrou, H. I. (1977.), Geschichte der Erziehung im klassischen Altertum, München: Alber.

Meyer, H. (1947.), Geschichte der abendländischen Weltanschauung, sv. 1. Die Weltanschauung des Altertums, Würzburg: Schöningh.

Neils, J. i Beaumont, L. (ur.) (2003.), Coming of Age in Ancient Greece. Images of Childhood from the Classical Past, New Haven: Yale Univ. Press.

Pache, C. O. (2004.), Baby and Child Heroes in Ancient Greece, Urbana and Chicago: University of Illinois Press.

Parker, J.-E. (2001.), Dialogic Education and the Problematics of Translation in Homer and Greek Tragedy, Lewiston: Mellen.

Schmid, K. A. (1892.), Geschichte der Erziehung von Anfang an bis auf unsere Zeit, Stuttgart: Cotta'schen Buchhandlung.

Scklafani, J. (2004.), The Educated Parent. Recent Trends in Raising Children, Westport, Conn.: Praeger Publishers.

Shay, J. (1998.), Achill in Vietnam. Kampftrauma und Persönlichkeitsverlust, Hamburg: Hamburger Ed.

Tenorth, H.-E. (2008.), Geschichte der Erziehung. Einführung in die Grundzüge ihrer neuzeitlichen Entwicklung, München: Juventa-Verlag. Wilamowitz, U. (1920.), Die Ilias und Homer, Berlin: Weidmann. 
DRUŠ. ISTRAŽ. ZAGREB GOD. 20 (2011),

BR. 1 (111)

STR. 249-267

PRANJIĆ, $M$. HOMEROVE ODGOJNE..

\section{Homer's Educational Values}

\author{
Marko PRANJIĆ \\ Centre for Croatian Studies, Zagreb
}

The author of the article reaches for the most representative work of European culture from Early Antiquity, Homer's Iliad and Odyssey. The aim is to demonstrate that certain parts of these works can be read and interpreted not only literarily but also pedagogically, although these are primarily epical literary works. By using the method of detection, he points out certain parts and verses, so he could hermeneutically, i.e. analytically draw attention to their educational and pedagogical value or meaning, and simultaneously interpret them in accordance with modern accomplishments of educational sciences. As the main frame for his research he applied the criteria of monitoring human growth in Homer's times throughout the human ages: childhood, preadolescence, adolescence, but there are also speeches about ideals and glory. In times when, because of certain life situations, social and consequently educational values are questioned, not as much on the level of the rejection of principles, as much in the practice which does not always follow them, he directs us to the sources so we could perceive the genesis and living of values in the beginnings of the European circle of civilization, which also includes Croatia.

Keywords: Homer, newborn, boy, young man, education, the educated, educator

\section{Homerische Erziehungsideale}

Marko PRANJIĆ

Kroatische Studien, Zagreb

Der Verfasser dieses Artikels greift auf eine Glanzleistung der europäischen Kultur aus frühantiker Zeit zurück - Homers Ilias und Odyssee. Er möchte zeigen, dass diese Werke nicht nur vorrangig als Literatur gelesen und interpretiert werden können, obwohl es sich natürlich in erster Linie um literarische Werke handelt, sondern zum Teil auch im Sinne pädagogische Handbücher. Durch Detektierung verweist der Autor auf einzelne Gesänge und darin auf bestimmte Verse, um im zweiten Schritt hermeneutisch bzw. analytisch auf den erzieherischen und pädagogischen Gehalt der Textstellen einzugehen und sie im Sinne zeitgenössischer pädagogischer Theorien zu interpretieren. Der Untersuchung liegen die zu Homers Zeiten beobachteten Altersstufen im menschlichen Heranwachsen zugrunde: Kindheit, Präadoleszenz und Adoleszenz, ebenso aber Überlegungen zu Vorbildern und 
DRUŠ. ISTRAŽ. ZAGREB GOD. 20 (2011), BR. 1 (111)

STR. $249-267$

PRANJIĆ, M.:

HOMEROVE ODGOJNE... gesellschaftliche und erzieherische Werte in Frage gestellt, wobei es nicht so sehr um ein Verwerfen dieser Werte im Vorhinein geht, sondern darum, dass die Lebenspraxis von bestehenden Vorbildern oft abweicht. Daher das Bedürfnis, auf Quellentexte zurückzugreifen, um auf die Herkunft bestimmter Werte zu verweisen, die das Leben im europäischen Zivilisationskreis bestimmen, zu dem ja auch Kroatien gehört.

Schlüsselbegriffe: Homer, Neugeborenes, Junge, Jüngling, Erziehung, Zögling, Erzieher 